\title{
COMPUTATIONAL MECHANICS IN SCIENCE AND ENGINEERING - QUO VADIS
}

\author{
Peter Wriggers, Fadi Aldakheel, Michele Marino, Christian Weißenfels
}

\begin{abstract}
Computational Mechanics has many applications in science and engineering. Its range of application has been enlarged widely in the recent decades. Hence, nowadays areas such as biomechanics and additive manufacturing are among the new research topics, in which computational mechanics helps solve complex problems and processes. In this contribution, these emerging areas will be discussed together with new discretization schemes, e. g. virtual element method and particle methods, whereby the latter need high performance computing facilities in order to solve problems such as mixing in an accurate way. Failure analysis of structures and components is another topic that is developing fast. Here, modern computational approaches rely on the phase field method that simplifies discretizations schemes. All these approaches and methods are discussed and evaluated by means of examples.
\end{abstract}

Keywords: virtual element methods; biomechanics; additive manufacturing; phase field methods; discrete element methods; fluid-particle interaction.

\section{INTRODUCTION}

The phrase "computational mechanics" comprises two words. The second one is associated with an "old" part of physics, which is brought by the first word into a modern multidisciplinary area. Computational mechanics nowadays plays a key role in solving problems in Engineering, Science and Medicine (Biomechanics). It combines Continuum Mechanics, Applied Mathematics, Computer Science and Modeling Techniques, and hence merges different fields and methodologies in a multidisciplinary sense to a scientific approach that helps understand physical, chemical and other phenomena in science and engineering. These types of multidisciplinary applications are today a necessity for scientific and engineering advancement. The basic phases in a computational mechanics 
process are modeling, selection of a discretization scheme, software development, numerical simulation, and validation.

In this contribution, we will discuss recent developments with respect to discretization techniques and future trends in Computational Mechanics that are related to modeling and multiphysics applications.

\section{MODELING}

Models are required for the prediction of processes, developments and durability in science, business and engineering. In engineering and science, it is generally not possible to apply a full-scale model for a problem at hand, which is due to the large structures that have to be designed. Here the length scale difference can easily be of the order of 1000. The same is due for time scales, since processes at microstructural or atomistic level are a lot shorter than at macroscopic level when describing the behavior of a material. Hence, models have to be derived for different length scales. In engineering and science, one could start from an atomistic description of materials. However, due to the complexity and size of the problems, this is often not the adequate modeling approach. Furthermore, the molecular dynamics approach which is related to nano- and micrometer scales, is not always feasible. Thus, there is need for a continuum approach based on the theory of continuum mechanics. Even with these - in general three-dimensional - models, it is generally not possible to design real engineering structures. Thus, reduced models - such as trusses, beam, plates and shells - derived from the general threedimensional continuum equations or other techniques to reduce the order of a complex, have to be applied to be able to reproduce the main structural behavior of the building. They are consistent with the model assumptions and may be validated by experimental data.

Model development in science and engineering is related to the length and time scales that have to be considered. If the interaction of atoms is of relevance, then the Schrödinger equations have to be solved. This is very complex and time-consuming, and is hence only used if the interaction forces between atoms are of interest. The next length scale is provided by molecular dynamics of atoms with known force relations between the atoms. Here, large dynamical systems of many molecules also have to be solved at a length scale of nanometers. Additionally, also a correct time resolution has to be considered when solving these equation set; thus, only shorter time periods can be predicted. Such models can be applied to model chemical reactions, biological cells or material behavior at atomic length scale. The models are very accurate, but due to their complexity, they cannot be used as predictive tools for many applications. In order 
to overcome this difficulty, it is necessary to coarsen such models, which lead to continuum models that include atomistic or molecular structures in a smeared way within the constitutive relations. These models are classically applied for most predictions in engineering, biomechanics and physics.

In the next step, we focus on the modeling process in engineering.

Modeling Process. Engineers have to make prediction for objects such as structures, machines, cars, airplanes, but also medical devices and structures in biomechanics. This starts with a design goal, and then the real physical behavior of the object has to be projected onto a model that can accurately predict the response of the object in the application range that is set by the design goals. Often the model will not lead to the expected results, and a different or refined model will have to be generated. A generic cycle is depicted in Fig. 1. It includes the steps leading to a proper model.

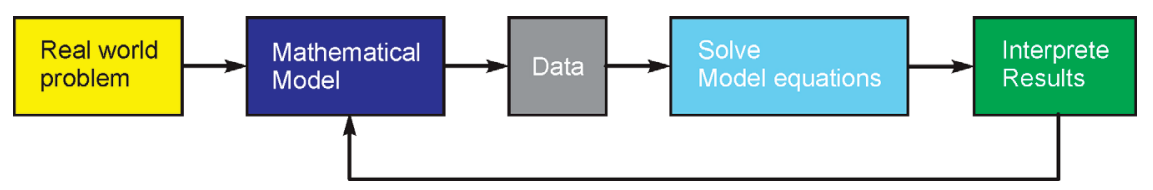

Fig. 1. Model development from the real world to mathematics.

Sl. 1. Razvoj od realnog problema do matematičkog modela.

One of the main steps in this process is the construction of the model. Most frequently, an existing model is used - amended in such a way that it reproduces the behavior of the real world object. However, the development of a completely new model is also possible when the real world problem demands a new approach.

Another major step is the collection of proper data. In engineering, this includes the action of a surrounding medium, dead loads and other loads. Additionally, initial conditions of states and boundary conditions have to be considered. These data often have random character and thus bring uncertainties into the model. Data collection can also invoke a refined process when it turns out that e.g. actions of the surrounding medium air or water - have to be predicted by a model itself, that has then to be coupled with the structure leading to a so called fluid-structure-interaction problem.

Once the mathematical formulation of the model is finished the set of algebraic or differential equations has to be solved. For this purpose, a proper method has to be selected. Here, the engineer needs sufficient mathematical background and knowledge in engineering theory, such as continuum mechanics, in order to select a solution scheme that provides reliable results in the most efficient way when e.g. nonlinear problems are addressed. Here, we have to ask the question: Do we solve the equations right? 
Within the last step, the model results have to be interpreted and validated. This is of utmost importance, since the reliability of a model depends on good validation. The latter word means: Are the model equations correct? This question can be answered by experiments if possible or by the knowledge of the engineer who can judge the results by experience. Furthermore, simplified models can be used to access general correctness.

On a first view, it seems that all steps can be carried out one after another. However, it is obvious that the last and the first step are connected, since a change in the model can be caused by the validation. However, the mathematical model might also have to be changed if the interpretation of results suggests a new mathematical model. Thus, instead of going back to the first step, the loop is now just from the fourth to the third step. And again, the loop can also be formed from the validation step to the data collection, and thus different paths might have to be followed in the process of projecting real world problems onto a model.

Theoretical background. New models have to rely on a sound theoretical formulation that leads in general to a set of partial differential equations. The general equation set formulates time-dependent problems in three-dimensional space. The basis for setting up the correct equation set for a continuum mechanics problem is given by the following general structure:

- Kinematics: deformation, displacements, rotations and velocities.

- Balance laws: balance of mass, momentum, momentum of momentum, the first and the second law of thermodynamics.

- Constitutive relations: assign quantities from kinematics to stresses. These equations have to be selected related to the material under consideration and can thus only be determined from experimental data or from atomistic scale computations with respective homogenization.

All of these laws and relations lead to partial differential equations that are in general nonlinear. The general formulation can be specialized for solids and fluids. But often, for more complex applications, coupled sets of equations are needed in order to include multi-physics like temperature, diffusion and other transport phenomena.

Many current topics need new modeling processes. Here, we chose to focus on several topics that are associated with emerging areas, such as special discretization techniques, discrete element method and particle-laden flows, as well as new models for additive manufacturing and biomechanics. 


\section{DISCRETIZATION TECHNIQUES}

During the last sixty years, the finite difference method, the finite element method, and the boundary element method were developed; they are now ready for application in engineering design problems. Many of these methods cover the problem ranges that are described above (e.g. small/large strains, different constitutive equations or coupled field equations). Additionally, new approaches, such as meshless methods for arbitrary deformations, isogeometric analysis, and the extended finite element method (XFEM) for fracture mechanics problems evolved and can be efficiently used within a specific problem range. Thus, the art of modeling means here picking the right numerical solution method that provides accurate results in the most time-efficient way.

Each of the methods described above has its own specifications and thus needs experts for correct and efficient application. As an example: within the finite element method, there are hundreds of different finite element formulations for different applications that can even fail when applied to an inadequate problem. The same is true for all the other methods.

Here, a relatively new method - the virtual element method, which can be an alternative for specific problems - will be presented. The authors of the method were F. Brezzi and coworkers, see [5].

\subsection{Virtual Element Method (VEM)}

The virtual element method was developed during the last decade and applied to problems in elasticity for small strains and other areas in the linear range. Extensions of the virtual element method to problems of compressible and incompressible nonlinear elasticity and finite plasticity have been reported in the last years. Low-order formulations for problems in two and three dimensions, with elements being arbitrary polygons or polyhydra, are considered. Various formulations considered are based on the minimization of energy, with a novel construction of the stabilization energy.

The structure of the VEM typically comprises a term in the weak formulation or energy functional, in which the displacement $\boldsymbol{u} h$ (with the nodal degrees of freedom $\boldsymbol{u}_{I}$ ), being sought, is replaced by its projection $\boldsymbol{u}_{\pi}$ onto a polynomial space (see Fig. 2). 


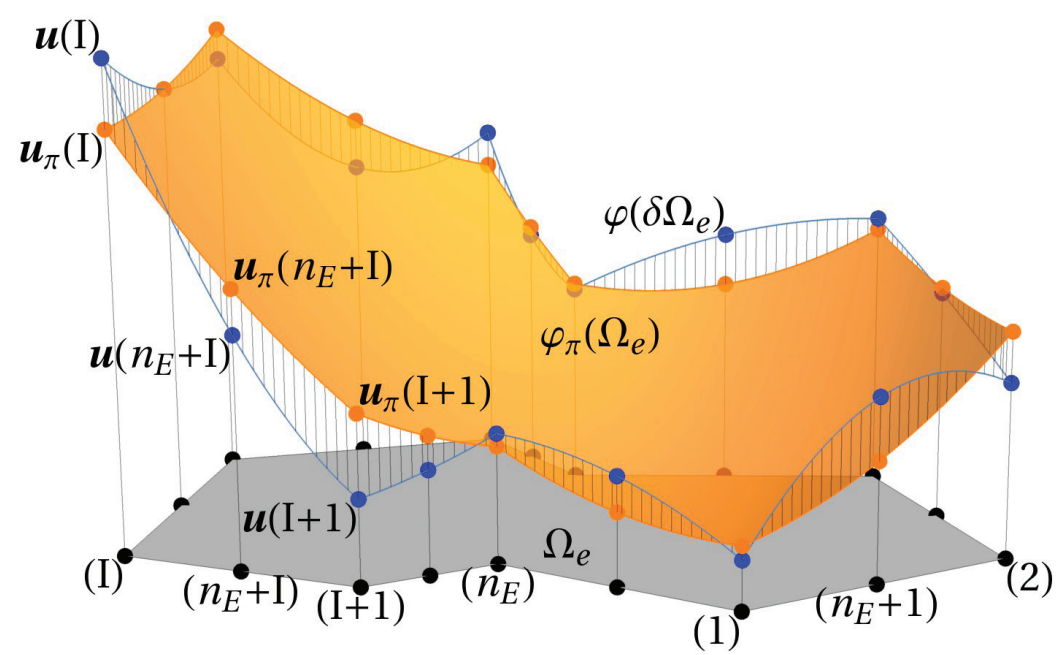

Fig. 2. Projection of an arbitrarily shaped element onto an ansatz space using a quadratic polynomial.

SI. 2. Projekcija elementa proizvoljnog oblika u područje interpolacije korištenjem polinoma drugog stupnja.

This results in a rank-deficient structure, so that it is necessary to add a stabilization term to the formulation. The stabilization term is generally a function of the difference $\boldsymbol{u}_{h}-\boldsymbol{u}_{\pi}$ between the original variable and its projection. In order to adhere to a fundamental aspect of VEM, in which all integrations take place on element boundaries, the stabilization term proposed (see e.g. [5]) takes the form of a sum of a function of nodal variables. This is the approach adopted in some nonlinear investigations with the scalar stabilization parameter of the linear case being replaced by one that depends on the trace of the fourth-order elasticity tensor.

For another formulation of VEM that uses a different stabilization technique, see [24]. The essence of the method is the addition to the positive semi-definite mean strain energy $\Psi$ a positive-definite energy $\hat{\Psi}$, which is evaluated using full quadrature, and for consistency subtraction of a term involving $\hat{\Psi}$ as a function of the mean strain. The strain energy is then the sum of $\Psi\left(\boldsymbol{u}_{\pi}\right)+\left[\hat{\Psi}\left(\boldsymbol{u}_{h}\right)-\hat{\Psi}\left(\boldsymbol{u}_{\pi}\right)\right]$, the original energy as a function of the projected displacement, and a term in which a positive definite stabilization energy as a function of the displacement and its projection are respectively added and subtracted. The second term vanishes when the element size goes to zero. 
The methodology can be applied for compressible and incompressible elastic and inelastic materials. Some examples of this new promising discretization scheme are discussed below.

\subsection{VEM for hyperelasticity}

Once the projection of the virtual element method is known, which in case of linear polynomials can be computed directly (see [24]), it is simple to compute the constant deformation gradient related to the projection $\boldsymbol{u}_{\pi}$ within a virtual element. This computation only involves an integral over the boundary of the virtual element. Once the deformation gradient is known, quantities like the left Cauchy Green tensor and its invariants that enter the strain energy function can be easily obtained. Hence, the strain energy $\Psi\left(\boldsymbol{u}_{\pi}\right)$ can be computed, and by using the software tool AceGen (see [13]), the residual and tangent stiffness related to that strain energy function follow.

The stabilization needed to obtain a virtual element with correct rank is based on the strain energy difference $\hat{\Psi}\left(\boldsymbol{u}_{h}\right)-\hat{\Psi}\left(\boldsymbol{u}_{\pi}\right)$, see [24]. The second term can be computed in the same way as $\Psi\left(\boldsymbol{u}_{\pi}\right)$. For the first term of the stabilization part, internal triangularization is used, which involves only the boundary nodes of the virtual element. Here, linear triangles or tetraheders are used, which again leads to constant strains per internal element and yield an efficient formulation of the virtual element.

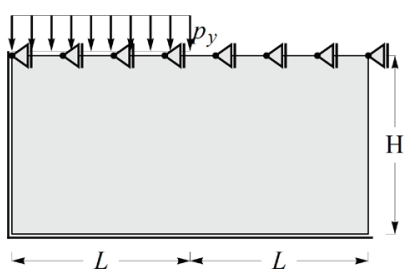

a) BVP

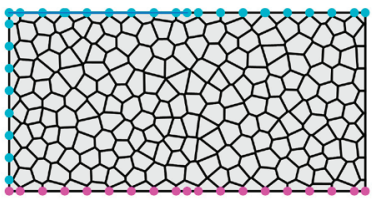

b) Voronoi

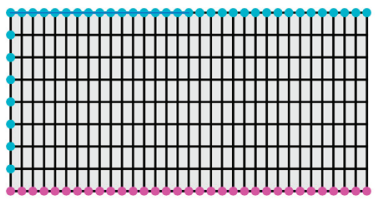

c) Q1/Q2S

Fig. 3. Punch problem and different mesh types.

SI. 3. Problem utiskivanja i različite vrste mreža.

As an example, we consider the punch problem depicted on the left side in Fig. 3. The punch is on rollers at the bottom and the left side. The displacement at the top is restricted, so that it can only deform vertically. A uniform load is applied at the top on the left half of the punch. A Neo-Hookean strain energy is used with a Young's modulus of $\mathrm{E}=240 \mathrm{kN} / \mathrm{mm}^{2}$ and a Poisson ratio of $v=0.3$. The length $\mathrm{L}$ and height $\mathrm{H}$ have the same value of $1 \mathrm{~mm}$. A total load of $800 \mathrm{kN} / \mathrm{mm}$ is applied leading to the deformed configurations shown in Fig. 4. 

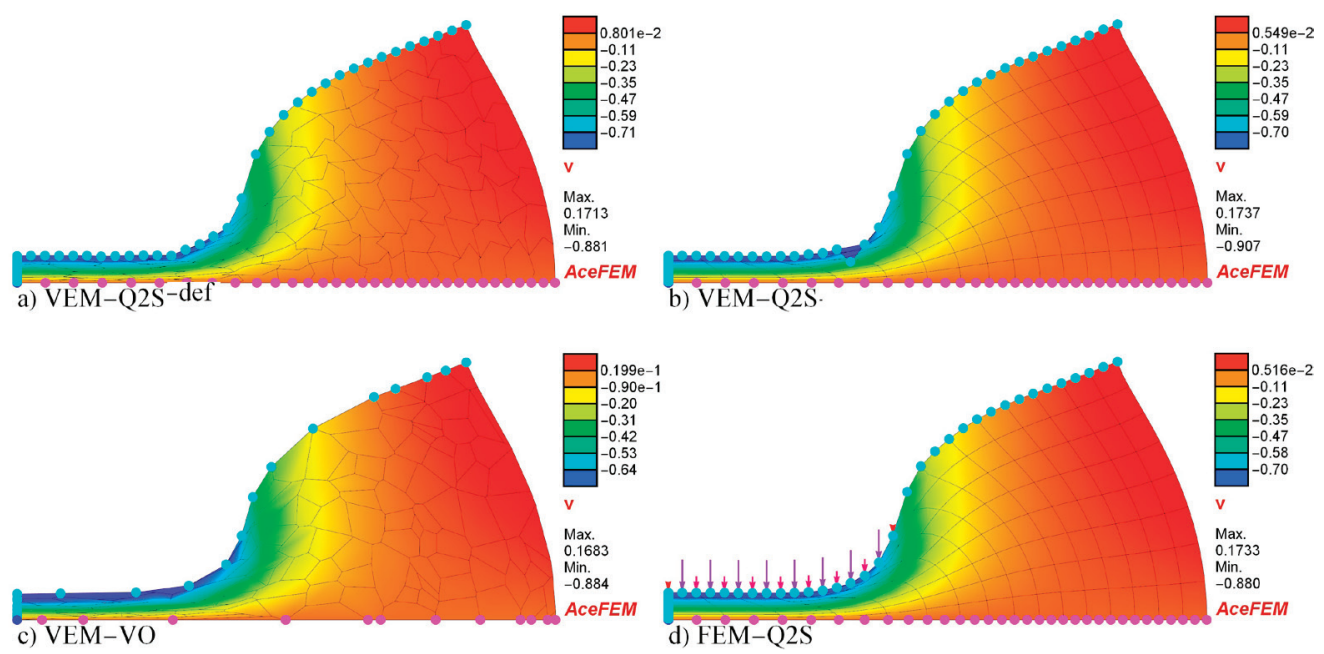

Fig. 4. Comparison of different discretizations.

SI. 4. Usporedba različitih diskretizacija.

Different types of meshes were used, as can be seen in Fig. 3 b) and c) on the right side. The meshes consist of 8 noded quadrilateral elements that are standard for a serendipity finite element mesh, here denoted by Q2S. The results for this type of mesh can be seen in Fig. 4 b) and d), whereby b) relates to a solution using the linear virtual elements with eight nodes, and d) depicts the solution when using quadratic serendipity finite elements. In Fig. 4 a), the Q2S mesh is distorted by randomly positioning the nodes of a Q2S serendipity mesh. This leads even to non-convex elements. The solution is here obtained with virtual elements that directly discretize these elements. Finally, in Fig. 4 c), a randomly generated Voronoi mesh consisting of elements with different sizes was used.

All discretizations converge for a mesh size of $32 \times 16$ elements to the same solution, however, even when the meshes have only $8 \times 4$ elements, the deviation of the final vertical displacement under the load is less than $1 \%$ with respect to the converged solution.

\subsection{VEM for finite strain elasto-plasticity}

In contribution [12], the virtual element method using linear polynomial approximations was applied to finite strain plasticity. As an example, the torsion of a bar with square cross section was considered in [12]. 
The bar is subjected to a torsional load around $z$-axis at the center. The geometrical setup and the loading conditions of the specimen are depicted in Fig. 5(a). The height along the third direction $z$ is chosen to be $H=5 \mathrm{~mm}$, and the length of the square crosssection is set to $L=1 \mathrm{~mm}$. At the boundaries, we fixed the bottom end of the bar and applied torsion to the top end, as depicted in Fig. 5(a). The elongation along the third direction $z$ at the top surface is linked, i.e. $\Delta w_{i j}=w_{i}-w_{j}=0$. Different element formulations are studied to illustrate the robustness of the proposed virtual element method. A Voronoi mesh of about $9 \times 9 \times 36$ elements was used; this is depicted in Fig. 5(b).

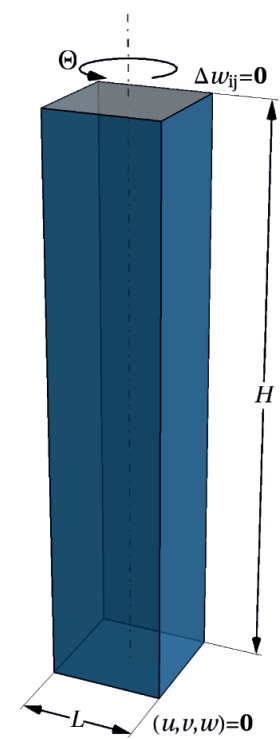

(a) BVP

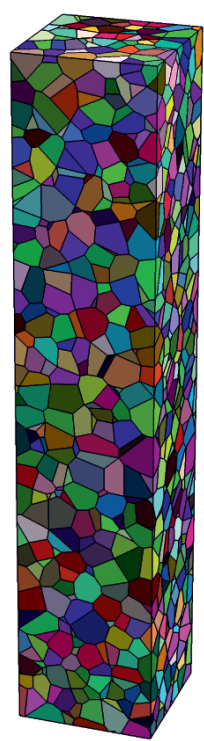

(b) VEM - VO

Fig. 5. Numerical torsion test of a square-section bar. (a) Geometry and boundary conditions; (b) Voronoi mesh used in the numerical analysis for $9 \times 9 \times 36$ elements.

SI. 5. Numerički test uvijanja štapa kvadratnog presjeka. (a) Geometrija i rubni uvjeti (b) Voronoijeva mreža korištena u numeričkoj analizi za $9 \times 9 \times 36$ elemenata.

Figure 6 demonstrates the distribution of the equivalent plastic strain $\alpha$ using VEMVO for different rotation angles until one cycle $\Theta=360^{\circ}$ is completed. In comparison with the standard, the virtual element formulation provides as good solutions as a H1-P0 element. A cut through the bar was made in both the contour plots (results: Figure 6) to illustrate the plastic evolution inside the specimen along with the deformed elements. 

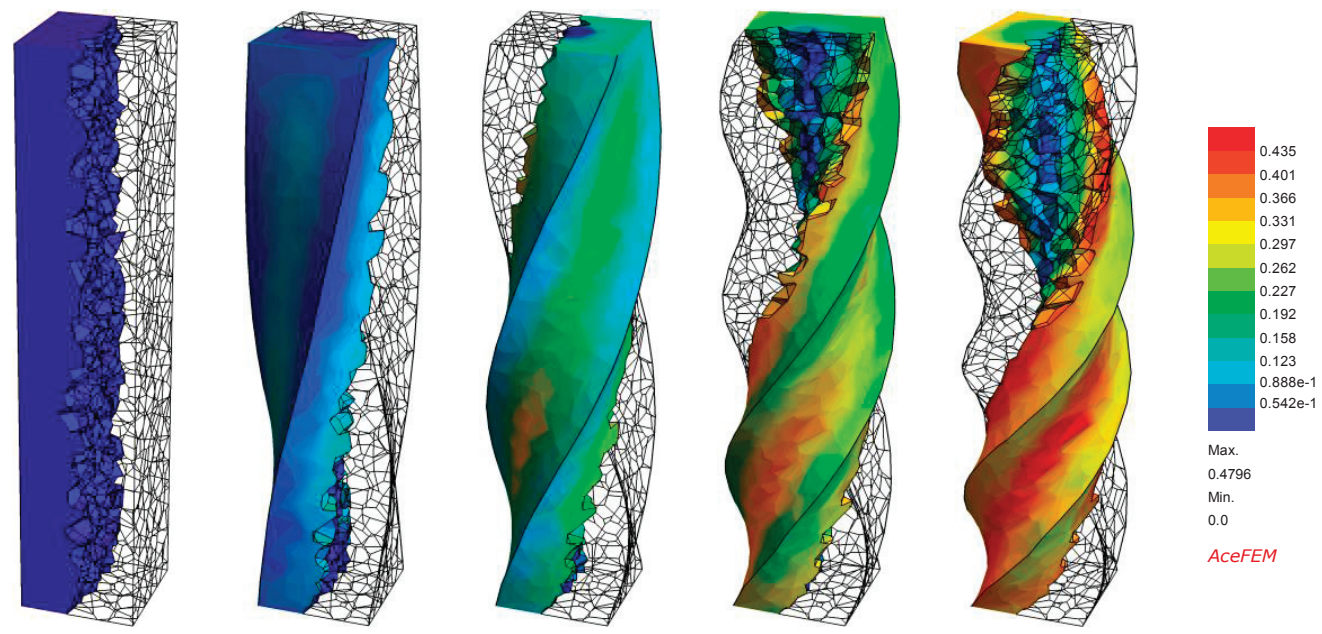

(a) $\Theta=0^{\circ}$

(b) $\Theta=90^{\circ}$

(c) $\Theta=180^{\circ}$

(d) $\Theta=270^{\circ}$

(e) $\theta=360^{\circ}$

Fig. 6. Numerical torsion test of a square-section bar. Distribution of the equivalent plastic strain $\square$ for different rotations angles until the cycle is completed using the VEM-VO element.

SI. 6. Numerički test uvijanja štapa kvadratnog presjeka. Raspodjela ekvivalentne plastične deformacije $\square$ za različite kutove rotacije do postizanja punog ciklusa primjenom VEM-VO elementa.

\section{VARIATIONAL PHASE-FIELD MODELING}

The analysis of crack initiation and propagation in ductile materials has been a topic of intensive research recently, to predict failure mechanisms for various engineering applications. Machining, cutting and forming ductile materials are at the core of automobile, aerospace, medical fields, bridges or heavy industries. These applications can significantly benefit from a precisely predictive computational tool to model ductile fracture in the design phase of products. 
Numerical tools for the prediction of fracture initiation and propagation are numerous (see [15]). Besides boundary and finite element methods for linear elastic fracture analysis, different versions of the so-called eXtended Finite Element Method (XFEM) are applied. The underlying methodology is based on the enhancement of the internal element shape functions by modes that account for the fracture. This method is well developed and even used in the context of multiscale applications in which micro cracks are modeled; they can later grow into macro cracks leading to failure of a structural element; for details see e.g. [11].

Starting with the work of [7], fracture processes were modeled by a phase-field approach. Due to its simplicity, this methodology has gained wide interest und has been used in the engineering community since 2008. From there on, many scientists have worked in this field and developed phase-field approaches for finite elements, isogeometric analysis, and lately also virtual element technology (see [3]). The main driving force for these developments is the possibility to handle complex fracture phenomena within numerical methods in three dimensions. Thus, research on phase-field approaches is still vivid and points in many different directions. Three applications can be found in the next sessions.

\subsection{Brittle fracture}

The phase-field approach regularizes sharp crack surfaces within a pure continuum setting by a specific gradient damage modeling with constitutive terms rooted in fracture mechanics. The key goal of the development is to present a consistent variation-based framework for the phase-field modeling of isotropic brittle fracture. It is based on a constitutive work density function and a dissipation function with threshold for fracture, which together define a minimization principle for the coupled problem. The work density function is decomposed into: (i) An energetic part defined to be exclusively elastic in nature, which represents a degraded elastic free energy density. Besides the constitutive expression for the stresses, it also provides a locally energetic driving force for regularized fracture. (ii) The dissipative part governs fracture resistance with the inclusion of a fracture length scale parameter. For brittle fracture, the material response corresponds to the sequence: $E$ (elastic) - F (fracture). 
a)

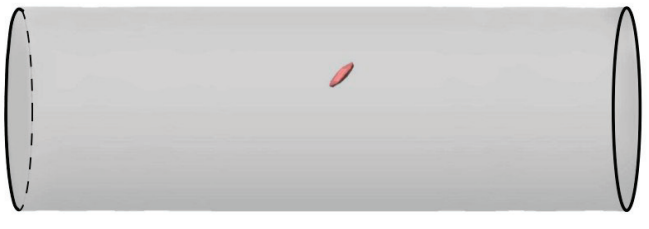

b)

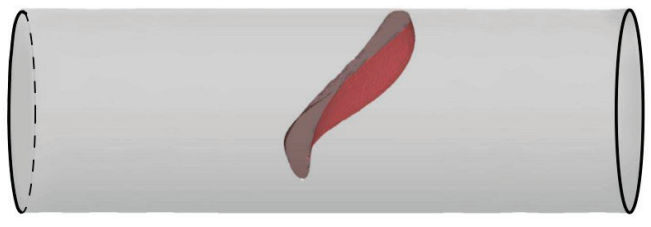

c)

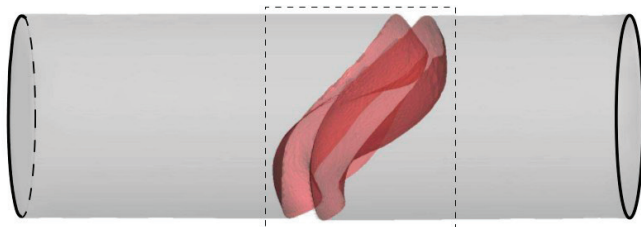

d)

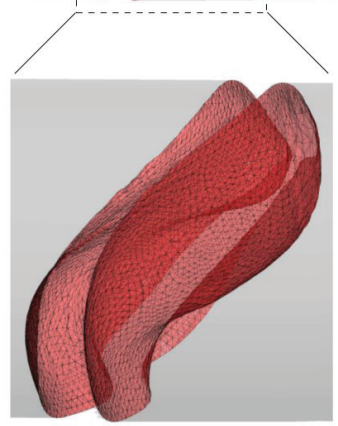

Fig. 7. Three-dimensional torsion test of a cylindrical bar. (a)-(c) Contour plots of the fracture phase-field $d$ evolution in brittle (Elastic-Fracture) cast-iron for a twist loading. (d) Visualization of the crack faces.

Sl. 7. Trodimenzijski test uvijanja cilindričnog štapa. (a)-(c) konturni prikaz razvoja lomnog faznog polja $d$ u krtom (elastični lom) lijevanom željezu za opterećenje uvijanja.

(d) Prikaz lomnih ploha.

On the computational side, one may employ either a monolithic or a staggered algorithm to compute the unknowns, in which the displacement and the crack phase-field are computed simultaneously or alternatively, respectively. Herein, a robust and efficient monolithic scheme is employed in the numerical implementation using the software tool AceGen (see [13]). 
As an example, the three dimensional torsion test of a cylindrical bar was considered in [2]. The evolution of the crack phase fi $d$ for the cast-iron bar is depicted in Fig. 7. The crack starts to initiate at a point on the surface near the center of the specimen at an angle of twist of $1.1^{\circ}$ (see Fig. 7a). Then it propagates from the surface inwards until final rupture in Fig. 7c. To illustrate the crack surface, we zoomed out the fractured area as shown in Fig. 7 d. Since the fracture path is about $45^{\circ}$ from the longitudinal direction, the fracture surface is complicated and looks like a helicoids. Here, we used a transparency effect to show the failure surface for $d \geq c \approx 1$.

\subsection{Ductile fracture}

Most metals fail in a ductile fracture mode, preceded by considerable plastic deformation, in contrast to brittle or quasi-brittle materials, where fracture occurs without noticeable permanent deformation, as discussed above. The modeling of failure in ductile materials must account for complex phenomena at micro-scale, such as void nucleation, growth and coalescence, the formation of micro-shear-bands and micro-cracks, as well as the final rupture at the macro-scale.

A large number of phenomenological and micro-mechanical approaches exist for the continuum modeling of ductile fracture. From the computational point of view, the tracking of sharp crack surfaces provides substantial difficulties and is often restricted to simple crack topologies. This difficulty can be overcome by recently developed phasefield approaches to fracture, based on the regularization of sharp crack discontinuities.

The novel aspect of this research is a precise representation of the framework in a canonical format governed by variation principles. The coupling of plasticity to fracture mechanics is realized by a constitutive work density function that includes the stored elastic energy and the dissipated work due to plasticity and fracture. The latter represents coupled resistance to plasticity and fracture, depending on the internal variables that enter plastic yield function and fracture threshold function.

In Fig. 8, the experimentally observed cup-cone failure mechanism of porous plastic solids in a round tensile bar is analyzed numerically. A huge plastic deformation as a necking zone with concentration hardening in Fig. 8a and void fraction in Fig. 8d at the specimen center, resulting in crack initiation at the center zone, as demonstrated in Fig. 8f. The crack phase field $d$ then propagates horizontally from the center outward along a zig-zag path. Thereafter, the failure mode changes to a shear mode, and the crack continues propagating at about $135^{\circ}$ from the loading direction to follow the equivalent plastic strain evolution path in Fig. $8 \mathrm{c}$ and the void volume fraction path in Fig. 8e, giving rise to the final cup-cone fracture surface. For visualization of crack surface, deformed regions with a crack phase-field $d \approx 1$ are not plotted. For details on phase-field porous ductile fracture, we refer the interested reader to Aldakheel et al. [1]. 
a)

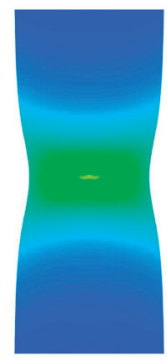

b)

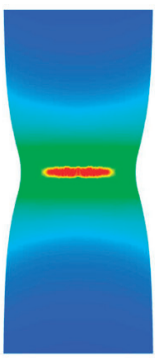

c)
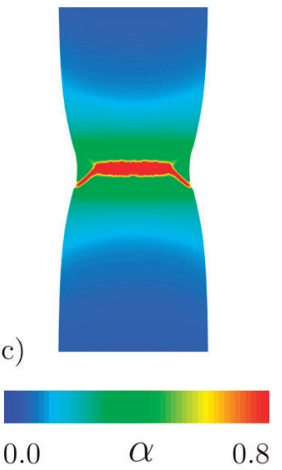

d)
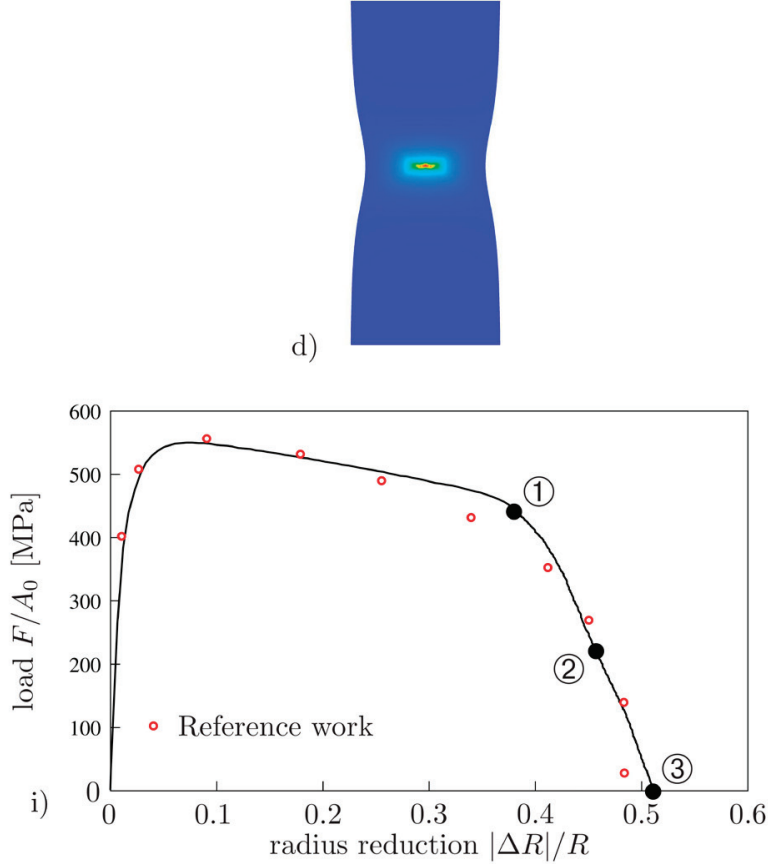

e)
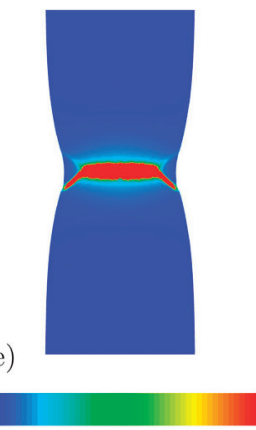

f)

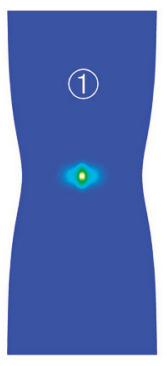

g)

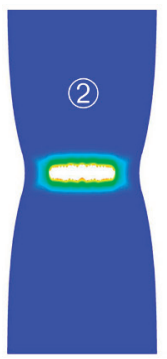

h)

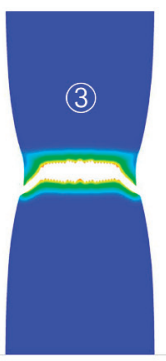

0.0

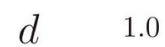

$$
15.10^{-5} f \quad 0.15
$$

Fig. 8. Cup-cone formation in axis-symmetric tension test. Contour plots of the hardening variable $\mathrm{u}$ in (a)-(c); the void volume fraction $f$ in $(\mathrm{d})-(\mathrm{e})$ and the fracture phase-field $d$ in $(\mathrm{f})-(\mathrm{h})$. Load (force $F /$ initial cross sectional area $A_{0}$ ) versus magnitude of the radius reduction $|\Delta R| / R$ curve in comparison with the reference work of Besson et al. [2001] is shown in (i).

SI. 8. Nastajanje Cup-cone oblika pri osnosimetričnom vlačnom testu. Konturni prikaz varijable očvršćenja ૧ u (a)-(c); volumni udio šupljina $f$ u (d) i (e) i fazno polje $d$ u (f) i (h). Krivulja medusobne ovisnosti opterećenja (sila F/početna površina poprečnog presjeka) i veličine redukcijskog polumjera $|\Delta R| / R$ u usporedbi s referenciranim radom Besson i drugi [2001] je prikazana u (i). 

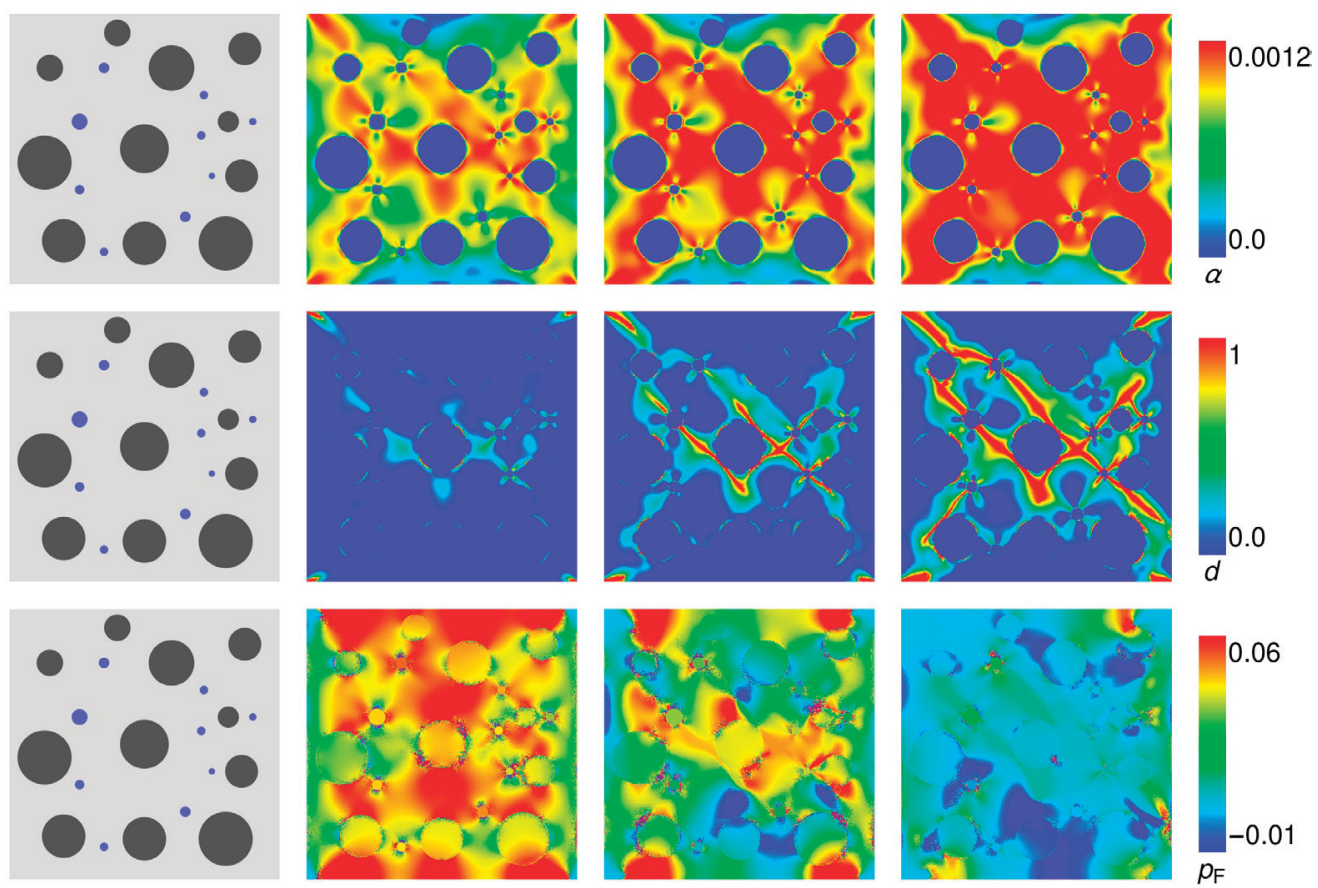

Fig. 9. Compression test for idealized microstructure of concrete specimen under water. Dark gray circles represent the stones, blue circles stand for water (saturated voids), and the rest with light gray color stands for the cement paste (mixture). Evolution of the hardening variable

$\square$, crack phase-field $d$ and fluid pressure $p F$.

SI. 9. Tlačni test idealizirane mikrostrukture betonskog uzorka pod vodom.

Tamnosivi krugovi predstavljaju kamenje, plavi krugovi su voda (natopljene šupljine) i ostatak označen svjetlo sivo je cementna pasta (mješavina). Nastajanje varijable očvršćenja $\mathrm{Q}$, pukotina faznog polja $d$ i tlak fluida $p F$.

\subsection{Multi-physics problems at fracture}

For new applications in multi-phase problems, water-induced failure mechanics for concrete based on the phase-field approach is investigated. The concrete has a highly hetero-geneous structure on different scales, and its composite behavior is very complex. Due to this, a variety of effects ought to be considered for analyzing failure response at micro-scale, e.g. modeling the solid skeleton, fl bulk phases and their interaction. To this end, the fracture phase-field formulations are extended towards Darcy-Biot-type fluidsaturated heterogeneous porous media at micro-to-macro-scale, see Fig. 9 as a preliminary result in this direction. 
The evolution of the equivalent plastic strain $\alpha$ (first row), the crack phase-field $d$ (second row) and the fluid pressure $p F$ (third row) are depicted in Fig. 9. The plasticity starts to accumulate around the stiff gravel, and the fluid pressure increases from the saturated voids. The crack starts to initiate in the plastic zones when the elasto-plastic energies reach a critical value. As expected, the fluid pressure however drops in the fractured areas as shown in Fig. 9.

\section{DISCRETE ELEMENT METHODS}

Discrete element methods are becoming an increasingly powerful tool, especially for the treatment of granular materials and in process engineering. The method can nowadays be applied to problems that need more than 10 million particles for an accurate model. These processes are run on high-performance parallel computers or GPU systems. The problem of the interchanging contact conditions due to large particle motions presents a challenge for the development of algorithms that scale well for large numbers of processors.

\subsection{Mixing of particles}

Here, we will focus on an application that uses the discrete element method to model the mixing process of different particles in a drum. In this application, the particles are mixed by rigid blades that rotate about the middle axis. The blades move up and down to perform the mixing. Here, millions of particles have to be considered, and many small time steps have to be executed to follow the complex motion of the particles in a mixer. Such problems necessitate the use of parallel computing machines with many cores. The problem is depicted in Fig. 10 a), which also shows the allocation of parts of the particles to a specific core of the parallel computer. In Fig 10 b), the velocity distribution during the mixing process is depicted. One can easily observe the complex movement of the particles that change locations and come into contact with other particles, thus leaving the location of the initial allocation and having to be moved to another core. This usually requires a reallocation and slows down the computation. In order to get good performance, sophisticated algorithms have to be used, which on the one hand have to be fast, and on the other limit data transfer. Thereby, a linear speed-up, even for a large number of processors, can be achieved (see Fig. 11). The blue curve shows the theoretical limit for a speed-up investigation up to 3500 processors. The red curve shows the performance for one algorithm, while the more sophisticated algorithm and related data handling amount to the green curve that produces an extremely good linear speed-up over all number of processors that reaches $66 \%$ of the theoretical limit. 

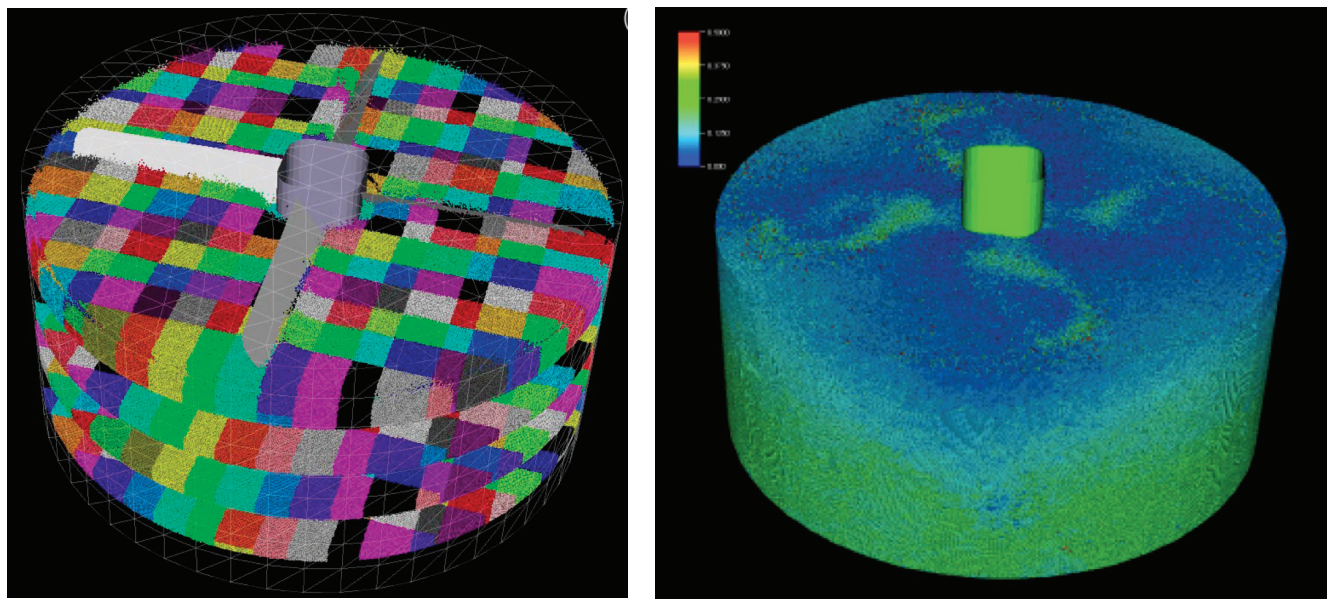

Fig. 10. a) Set-up of the particles in the mixer. The color code shows the allocation to a core in the parallel computer. b) Velocity distribution of the particles during mixing.

Sl. 10. a) Postavljene čestice u mikseru. Bojom označeni dijelovi pokazuju razmještaj u jezgri paralelnog računala. b) Raspodjela brzine čestica za vrijeme mješanja.

\subsection{Particle Flow}

Particle flow is governed by combining fluid mechanics with particle mechanics. Thus, the field of Computational Fluid Dynamics (CFD) is combined here with a discrete scheme based on the motion of distinct particles. Modeling of such flows requires different steps. On the one hand, the CFD model has to describe the fl using the NavierStokes equations. On the other hand, the motion of the particles has to be characterized by the classical equations for rigid bodies.

Different discretization schemes for the fluid can be employed. Among them are: finite difference schemes (see e.g. [8]), the finite volume approach (see. e.g. [10]), the Lattice Boltzmann method (see e.g. [14]), or the finite element method - to name only a few. In our approach, we use a finite element approach as developed in [20] leading to a computational fluid dynamics model, which has to be solved as an initial value problem (see [4]). The equations of motions describing the particle motion can be solved directly by a numerical integration scheme in time.

The interaction between the particles and rigid walls - describing the boundary of the fluid domain - is described by constitutive equations that take care of the approach of the particles, the friction at the interface and adhesive forces. The interaction between fluid and particles is modeled using an immersed technique, in which the fluid forces acting 
on the particle are considered as well as the obstacle resulting from particle geometry that influences the flow.

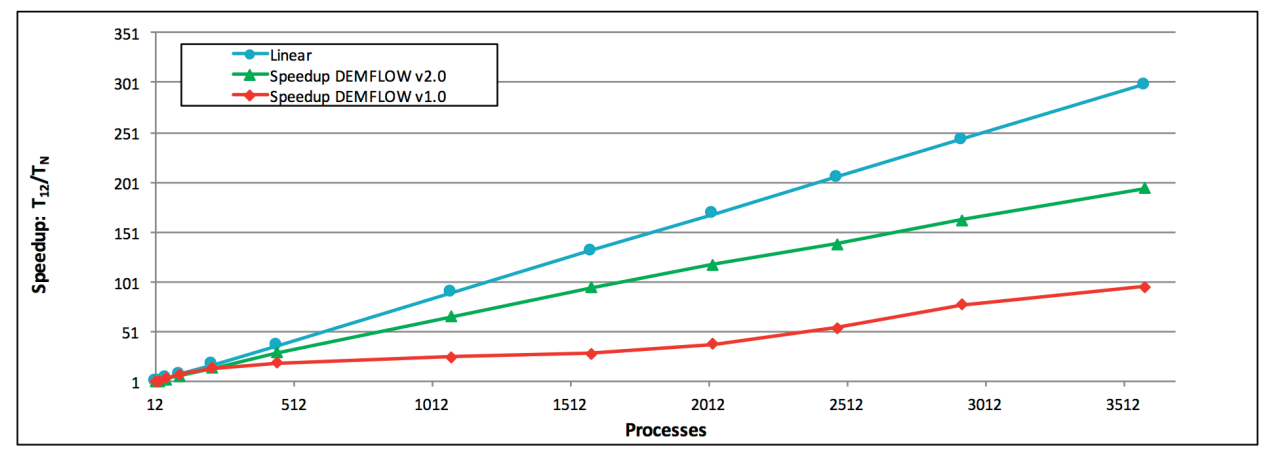

Fig. 11. Speed-up for different algorithmic treatments.

SI. 11. Ubrzanja za različite algoritamske postupke.
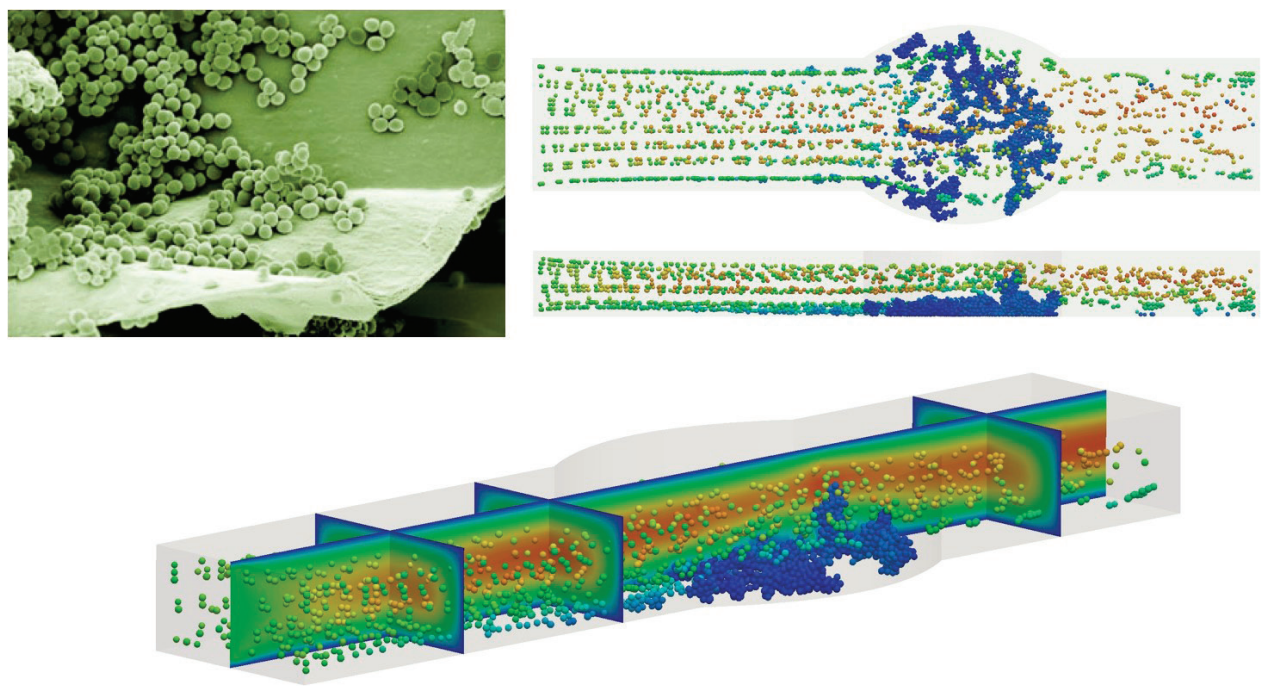

Fig. 12. Modeling biofilm growth using a particulate flow mode.

SI. 12. Modeliranje rasta biofilma korištenjem čestičnog strujnog moda.

The particulate flow model is now applied to the growth of a biofilm, where the molecules are approximated by rigid particles. Adhesion between particles and walls is considered such that particles in the fluid can adhere to each other and also to the walls. 
The channel (see Fig. 12) has a wider cross-section in the middle. Due to this, one can observe in Fig. 12 that the biofilm represented by the particles attaches to the surfaces in the middle of the channels, where the velocity of the flow is reduced. This is related to the decreased shear forces enforced by the flow on the particles.

\section{ADDITIVE MANUFACTURING}

Following the strategies of several governments, additive manufacturing will play a significant role in the digitalization of industry. This layer-by-layer 3D-printing process allows the production of mass customized products, e.g. patient specific implants, the building on demand of spare parts for aircraft or vintage cars, or the generation of new materials that exhibit desired mechanical, thermal, electrical, magnetic or optical behavior. The only input in this process is the data triple consisting of the digital model, the material composition and the process parameters. However, the physics of the whole process is not fully understood. Reproducibility, the control of the final physical properties, the quality assurance, and the automatization of the process chain are still barriers that limit comprehensive use in industry. The increase in computational power for mathematical modeling and simulation opens the possibility for scientific computing to play a significant role in the design of advanced manufacturing processes. However, classical simulation software, as the Finite Element Method for example, are ill-suited to simulate systems that are inherently discontinuous, such as additive manufacturing processes. However, meshfree computational methods are being developed - e.g. the stabilized Optimal Transportation Meshfree (OTM) method ([23]) or Smooth Particle Hydrodynamics (SPH), which are ideal for the simulation of these processes.

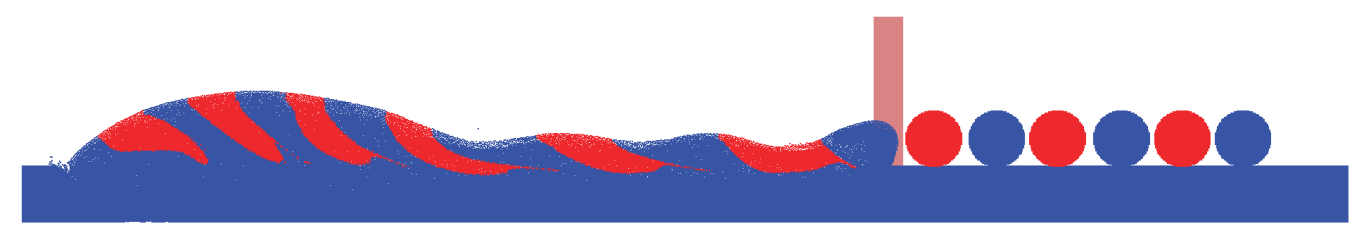

Fig. 13. Selective Laser Melting on the particle scale using "Implicit Smooth Particle Hydrodynamics"

SI. 13. Selektivno lasersko taljenje na skali čestice korištenjem metode "Implicit Smooth Particle Hydrodynamics" 


\subsection{Multi-physical modeling}

For including simulation software into the virtual development process, high fidelity models, which represent all the physical phenomena, are indispensable. In Selective Laser Melting (SLM) processes, the main interacting phenomena are laser matter interaction, heat transfer, phase transition, residual stress formation, and surface tension. The interaction with the process parameters laser power, scan rate, laser beam diameter, particle size, height particle layer and hatch spacing determine the quality of the printed component. Due to temperature, the state of each particle changes from solid to fluid and back to solid. The phase change approach, which models the whole solidification in a finite deformation framework suited to represent this effect in the SLM processes, can be found in [22]. Based on this, it can be demonstrated that the most important physical effect in Selective Laser Melting is surface tension. This effect is responsible for the fusion of two particles as shown in Fig. 15. If surface tension is neglected, only the thermal expansion of the particles can be observed.

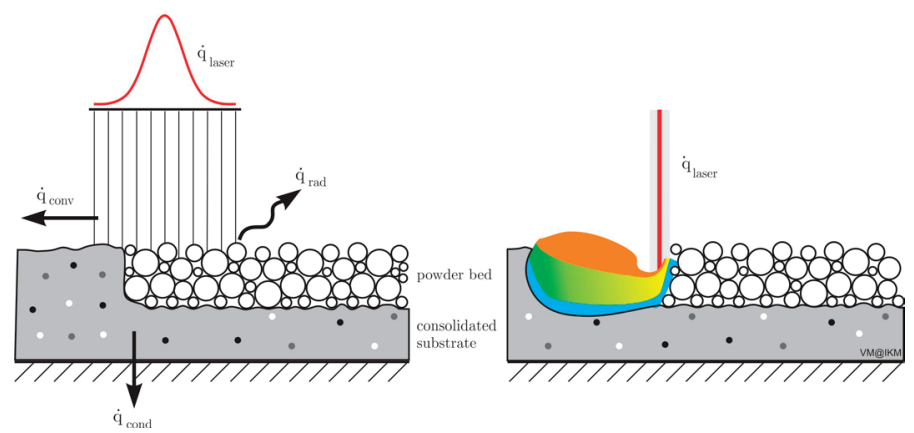

Fig. 14. (Left) Laser irradiation is emitted by thermal conduction, convection and radiation. (Right) Melt pool due to molten particles.

Sl. 14. (Lijevo) Lasersko zračenje uslijed toplinskog provodenja, konvekcije i radijacije. (Desno) bazen s talinom uslijed rastaljenih čestica.

\subsection{Influence of laser heat source modeling}

The laser matter interaction plays another central role in additive manufacturing processes. Laser emits power in pulses or continuously. Four stages of sophistication of laser modeling can be distinguished. The simplest form is the estimation of heating from the absorbed energy. Another simplification is a volumetric heat source model. 

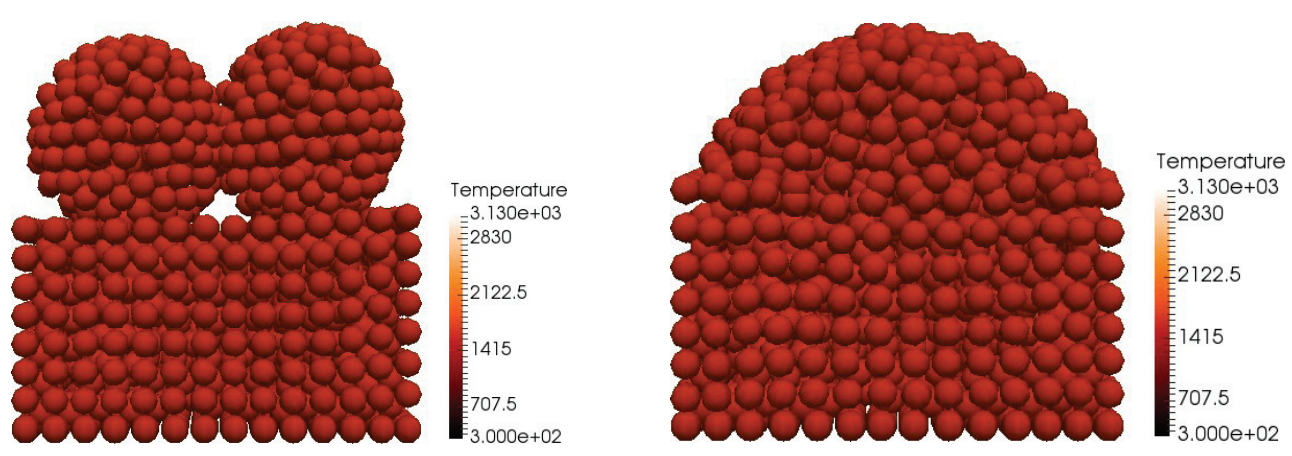

Fig. 15. Melting and solidification of two laser-irradiated particles using the stabilized OTM method, (left) neglecting and (right) including the surface tension effect.

SI. 15. Taljenje i skrućivanje dviju čestica ozračenih laserom korištenjem stabilizirane OTM metode (lijevo) zanemarivanjem i (desno) uključivanjem efekta površinske napetosti.
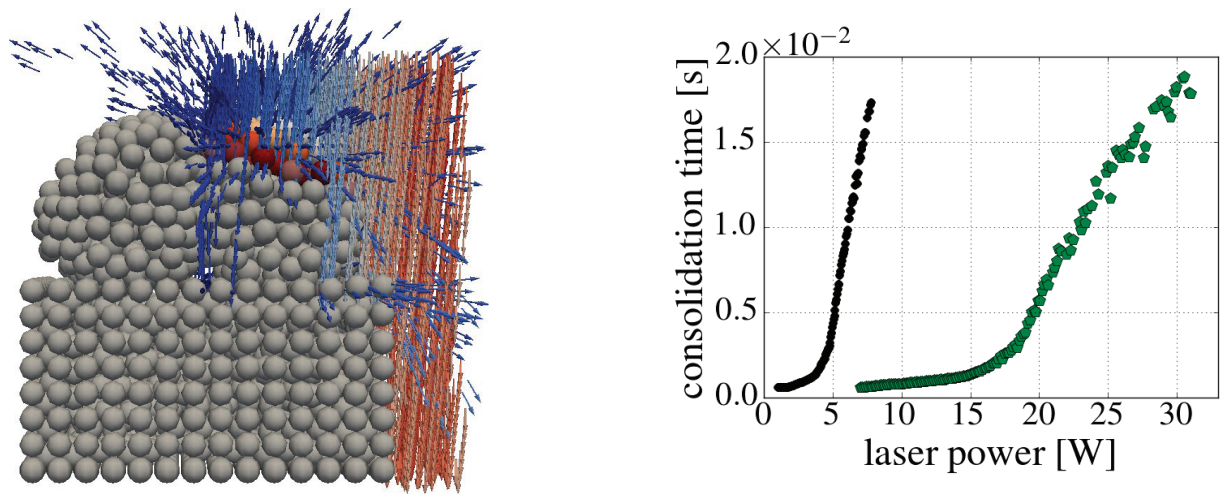

Fig. 16. (Left) Ray tracing approach coupled with the stabilized OTM method. (Right) Comparison of consolidation time between volumetric heat source model of [9] (green dots) and ray tracing approach (black circles).

SI. 16. (Lijevo) Postupak provlačenja zraka u spoju sa stabiliziranom OTM metodom. (Desno) Usporedba vremena konsolidacije izmedu modela toplinskog izvora [9] (zelene točke) i postupka provlačenja zraka (crni kružići). 
Discretizing the laser into rays is the next step of sophistication. The electro-magnetic Maxwell equations provide high accuracy of laser propagation, but the computational cost thereof is very high.

A coupling algorithm of ray tracing with meshfree methods can be found in [21]. The influence of the heat source modeling on the fusion of particles is also investigated therein. As shown in Figure 16, comparison between the volumetric heat source model for the SLM processes given in [9] and the ray tracing approach shows a different response behavior, although the absorbed energy is equivalent in both cases.

\section{COMPUTATIONAL BIOMECHANICS}

Advancements in computational methods for biomechanical applications can speed up the rate of scientific discovery in medicine and improve the effectiveness of clinical approaches. In silico analyses indeed reduce the need for experimental clinical trials, allowing to reproduce different pathophysiological scenarios in a rapid and low-cost way. In particular, computational biomechanics helps: (i) clarify the complex mechanobiological equilibrium that maintains physiological behavior; (ii) identify the relationships between histological and biochemical alterations with pathologies; (iii) gain a better understanding of the etiology of diseases; (iv) support the tailoring of clinical treatments to patient-specific features.

Personalized and effective numerical simulations for clinical applications need the patient-specific definition of geometry, applied loads/boundary conditions and material properties. While better While better patient-specific geometries are essentially related to progress in medical imaging technologies and reconstruction algorithms, advances in computational mechanics techniques can significantly increase the reliability of personalized boundary conditions and mate rialm properties. 


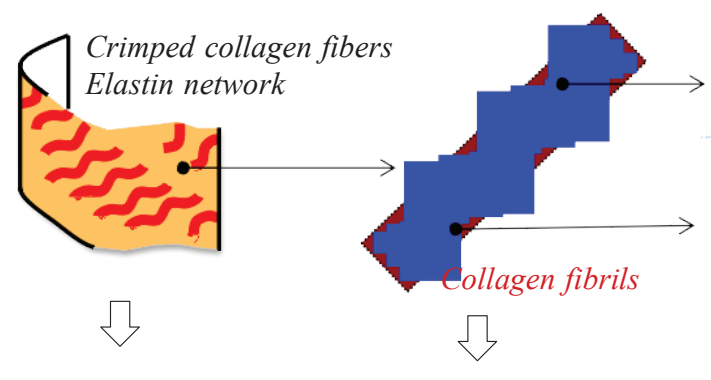

Fiber model

Fibril model

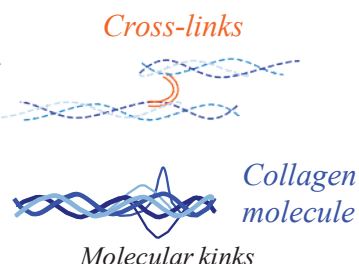

Molecular kinks (thermal fluctuations)<smiles>C1C2CC1C2</smiles>

Molecular model

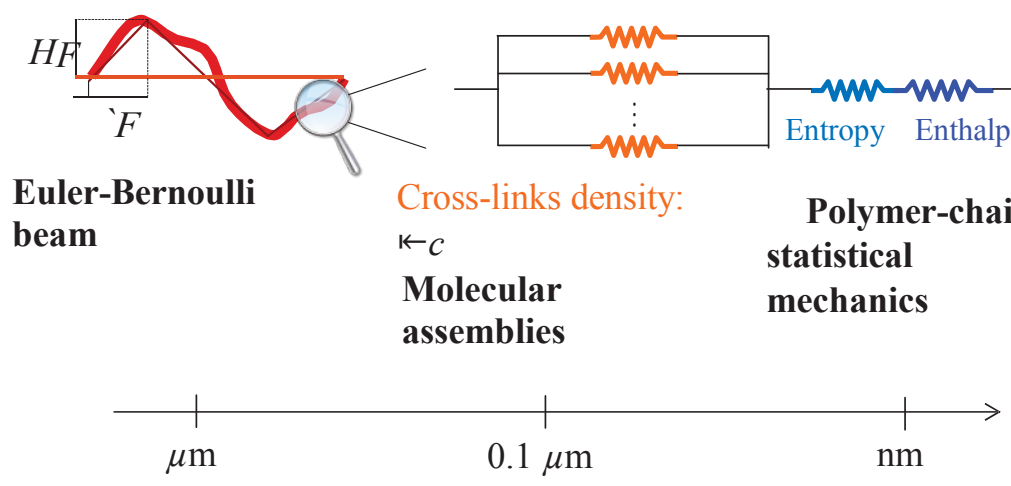

Fig. 17. Multiscale homogenization rationale for tissue constitutive nonlinearities: analytical description of crimped fibers (microscale), cross-linked molecular assemblies (meso(nano-to-micro) scale), and molecular elongation mechanisms (nanoscale).

SI. 17. Višeskalno homogenizacijsko načelo za konstitutivne nelinearnosti tkiva: analitički opis nabranih vlakana (mikroskala), poprečno povezani skupovi molekula (mezo (od nano do mikro) skala i mehanizmi izduženja molekula (nanoskala).

In order to introduce recent results in the field, an exemplary case of arterial blood vessels is addressed here. Computational analyses of arterial segments clearly require the solution of the fluid-structure interaction (FSI) problem. Nevertheless, with respect to a number of FSI problems in more traditional engineering contexts, these simulations are complicated due to the need of accounting for high constitutive nonlinearities and the complexity of the vascular system, which is made up by a series of interconnected branches. Indeed, accurate representations of both physiological and pathological flow conditions require a fine complete description of vessel wall mechanics and hemodynamics conditions. Moreover, pathologies are associated with an alteration of cell-cell signaling molecular pathways in tissues. Biochemical reactions indeed drive the concentrations 
of biologically active molecules. These substances play a crucial role in the synthesis/ degradation of the constituents of the extra-cellular matrix. Accordingly, they drive the growth and remodeling mechanisms of tissues in a complex balance that might bring to either tissue healing or pathological and uncontrolled modifications associated with mechanical dysfunctions.

In what follows, novel solutions for some computational challenges in biomechanics are discussed: multiscale homogenization approaches for tissue constitutive models; the FSI simulations accounting for constitutive nonlinearities and the up-/down-stream vasculature; multiphysics approaches for the chemo-mechano-biological description of growth and remodeling. Future trends in the field are also traced.

\subsection{Multiscale homogenization approaches}

The mechanical response of soft tissues is highly nonlinear and associated with a (quasi) incompressible behavior. The response is highly anisotropic and depending on the presence of collagen fibers embedded in an elastin network. Defects in the structure and arrangement of these constituents play a primary role in the onset and evolution of diseases. The challenge here is to incorporate structural information in constitutive models. In the state-of-the-art, widely-employed constitutive approaches are essentially based on phenomenological descriptions of the strain energy of collagen fibers, with their mean orientation being the only structural information [16]. Therefore, they generally exhibit a weak relationship between model parameters and tissue histological/biochemical features. Alternatively, multiscale homogenization approaches for soft tissues mechanics have been recently developed [16]. Among these, the rationale proposed by Marino and coworkers is based on an analytical description of the main mechanisms occurring down at the nanoscale (i.e. collagen triple helix elongation mechanisms), through the mesoscale (i.e. cross-linked molecular assemblies), up to the microscale (i.e. crimped fibers). The coupling of these models allocates macroscopic stress as function of micro- and nanostructural mechanisms (cf., Fig. 17). Hence, model parameters represent measurable histological and biochemical features across scales. This multiscale approach, originally developed in an updated-Lagrangian framework, has recently been formulated in a full-Lagrangian description by Marino and Wriggers [17].

\subsection{Multiscale FSI simulations}

The afore-introduced multiscale homogenization technique has also been implemented within FSI simulations. To this aim, an explicit time-marching approach has been adopted [6]. A physical coupling between the structural and the fl problem is performed by restoring compatibility and equilibrium relationships between the fl and solid 
domain at discrete time intervals along the cardiac cycle. The macro-time interval is then subdivided in separate $\mathrm{fl}$ and structure sub-steps. An Euler formulation in a rigid domain is considered for the fl problem, which describes the blood flow within a single macro-step. Boundary conditions are enforced on the basis of a 3D-0D coupling, which introduces a multiscale fluid description: inflow boundary conditions are read from experimental velocity flow profiles from the upstream vasculature, while the outflow boundary conditions are obtained from a three-element Windkessel model that accounts for the downstream vessels. In this way, the arterial segment model under investigation is embedded in the entire circulatory system. A Lagrangian description is adopted for the wall mechanics, computing structural displacements as function of the fluid pressure at the beginning of the current macro-step. At the next macro-step, the fluid domain is updated on the basis of wall displacements (i.e. from the solution of the structural problem), and structural loads are updated on the basis of the fluid flow (i.e. from the solution of the fluid problem), guaranteeing the FSI coupling.

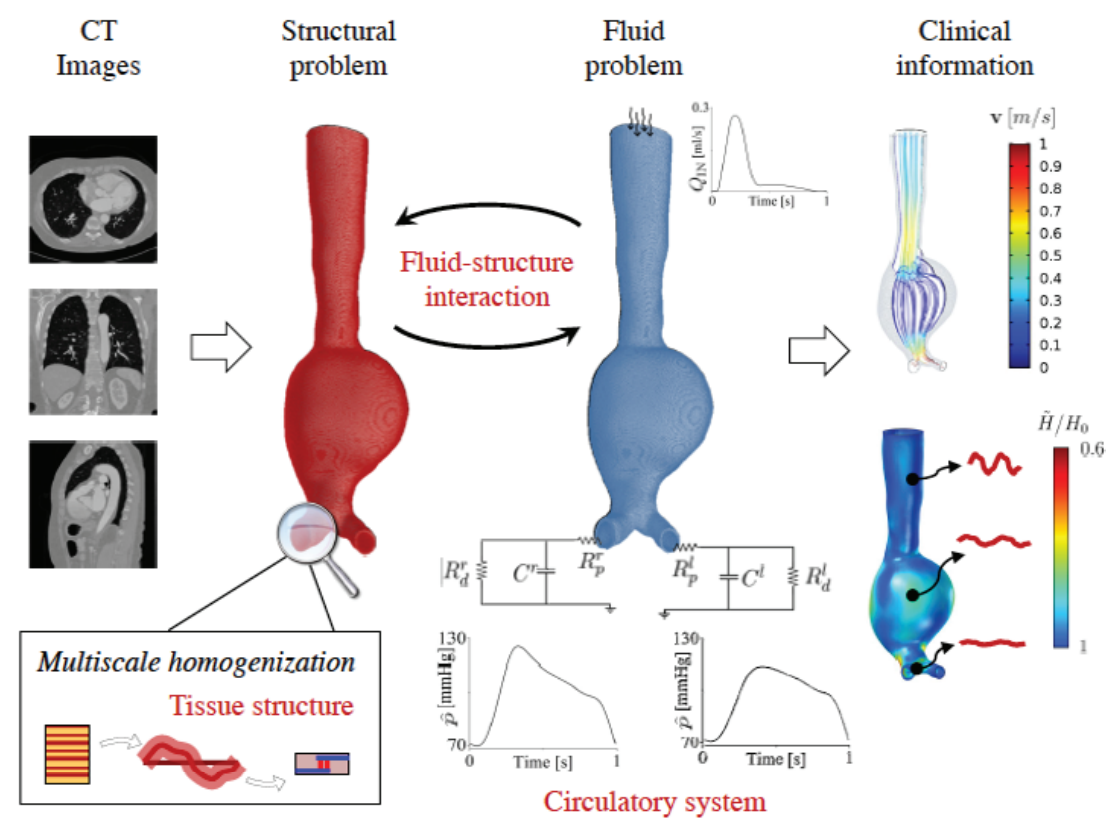

Fig. 18. Multiscale FSI simulations for clinical applications: coupling between the multiscale homogenization rationale for constitutive nonlinearities and a multiscale fluid description based on a 3D-0D definition of boundary conditions.

SI. 18. Višeskalne FSI simulacije za kliničke primjene: spoj između homogenizacijkog načela za konstitutivne nelinearnosti i višeskalnog opisa fluida temeljenog na 3D-0D definiciji rubnih uvjeta. 
Although the proposed strategy neglects advective effects induced by the wall moving within the fluid domain, the present approach has proved to be effective and accurate in a patient-specific model of aortic abdominal aneurysm (cf., Fig. 18). Thanks to the multiscale fluid rationale, the proposed strategy allows for obtaining classical fluid-related risk indices, as well as a novel insight on the coupling between tissue structural defects and the evolution of diseases or the rupture of blood vessels.

\subsection{Chemo-mechano-biological modeling}

The multiscale constitutive description of arterial tissues has also been coupled with a mechanistic modeling of cell-cell signaling pathways (modeled via transport diffusive equations) and biochemically-motivated remodeling laws of tissue structural features (inspired by the logistic function). The coupled multiphysical description has been solved by exploiting the separation of time scales between different phenomena. Therefore, staggered solution strategies have been implemented: the mechanical problem is assumed to be at steady-state for the transport problem, whose steady-state, in turn, influences tissue remodeling (cf., Fig. 19). Numerical results have been obtained by addressing a case study that shows the mechanical alteration of arterial physiological behavior as a consequence of tissue remodeling mechanisms induced by matrix metalloproteinases, transforming growth factors and interleukines [18].

\section{OPEN CHALLENGES AND FUTURE DIRECTIONS}

This overview tackled only some of the major areas within which Computational Mechanics moves. There are more complex models and refined discretization schemes that have to be robust and efficient in order to be applied in engineering and science. Some areas, such as material modeling at different length scales, fatigue modeling, stochastic analysis, and reduced order models have not been discussed in this contribution, though they too are of great interest. 


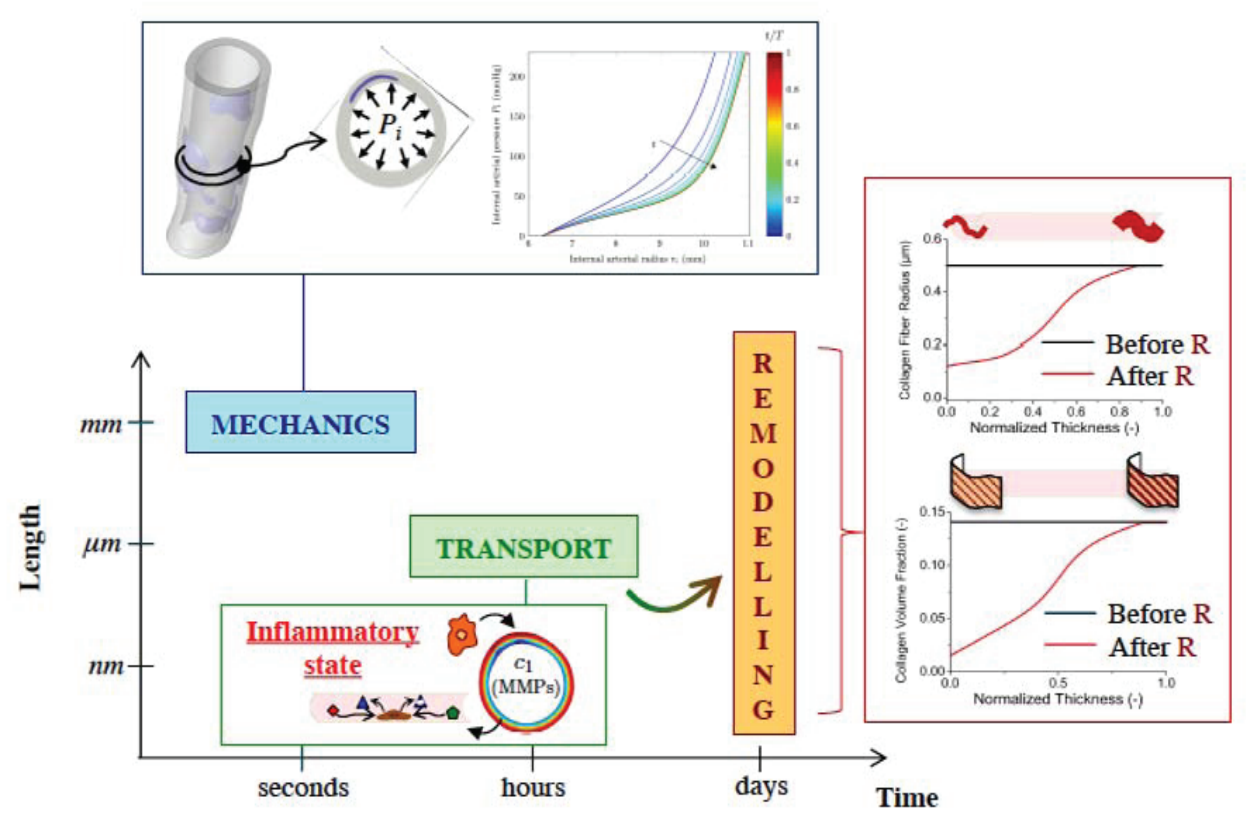

Fig. 19. Chemo-mechano-biological description of tissue remodeling: transport diffusive equations describe cell-cell signaling pathways; a logistic function introduces biochemically-motivated remodeling laws; the effects on arterial mechanics are analyzed thanks to the multiscale homogenization modeling rationale for tissue constitutive response. In the figure, $c 1$ denotes the concentration of matrix metalloproteinases (MMPs) as a consequence of an inflammatory state that triggers the mechanical dysfunction.

SI. 19. Kemijsko-mehaničko-biološko opisivanje remodeliranja tkiva: prijenosno difuzijske jednadžbe opisuju signalizirane putanje izmedu stanica; logističke funkcije uvode biokemijski motivirane zakone remodeliranja; djelovanja na mehaniku arterija su analizirana zahvaljujući načelu višeskalnog homogenizacijskog modeliranja konstitutivnog odziva tkiva. Na slici c1 označava koncentraciju matrice metaloproteinasa (MMPs) kao posljedicu upalnog stanja koje pokreće mehaničku disfunkciju.

\subsection{Discretization techniques}

Numerous discretization methods exist and are applied in the design of structures, components and processes. In mechanics, this means more complex tasks that models have to solve, including, inter alia, finite strains, nonlinear material response, and multi-physics. This means there does not exist one numerical method that could solve all problems. Instead, there is a wide range of methods, such as finite elements, virtual elements, finite differences, finite volumes, boundary elements, least square methods, 
fast Fourier transforms spectral methods, and so forth. The development state of most methods is on a very good level, however there are still challenges for specific applications in nonlinear mechanics. These are related to internal constraints, stability of formulations for finite deformations, etc. Among others, the research is conducted on highorder continuous and discontinuous Galerkin methods that offer high convergence rates. Furthermore, the virtual element method has to be further developed for applications in nonlinear mechanics and multi-physics.

\subsection{Phase-field approaches}

The phase-field approach has been proven to be a very powerful technique for simulating complex crack phenomena in multi-physical environments. In [3], the 2D phasefield approach was extended towards the recently developed virtual element formulation as outlined in Section 3, due to the flexible choice of nodes number in an element that can easily be changed during the simulation process. As a future direction, the 2D model of [3] will be further extended to a three-dimensional setting at finite strains. Open challenges due to this extension are: (i) the extra computational costs due to the additional amount of data required in the stabilization term to store the triangulation; and (ii) the preprocessing of meshes is more demanding in VEM (e.g. Voronoi 3D cells). These challenges will be investigated in future works.

\subsection{Modeling in biomechanics}

In terms of constitutive modeling approaches, current studies aim at optimizing the computational cost of multiscale descriptions. Moreover, the description of damage with a multiscale rationale would be a major advancement (see [19]). Addressing the FSI studies, a stronger coupling between the structural and fl problems might lead to more accurate evaluations when bigger movements of the solid within the fl are expected (e.g., dissections). In order to overcome this issue, future investigations will address the coupling of continuum-based and discrete-based approaches when both the structural and fluid problems are described by the means of a multiscale approach (see[4]). Finally, addressing the chemo-mechano-biological description of remodeling, monolithic solution strategies are being investigated, together with its coupling with a kinematic description of growth. Moreover, a better description of tissue reaction to injuries, and hence coupling with damage across scales, stays an open issue under investigation. 


\subsection{Additive Manufacturing}

To simulate the whole 3D-printing process based on the fusion of all individual particles is beyond the processing power of current computers. The multiscale approach (Fig. 20) is one option to evaluate the quality of the final manufacturing component by means of computational modeling. However, the selection of suitable data to be transferred from the particle- to the macroscale is a still an open question. On the other hand, in order to provide a high fidelity model for additive manufacturing, the information of the microscale have to be included into model. Another important step in finding the optimal model for additive manufacturing is the validation by the means of experimental observations. Therefore, a suitable benchmark test case has to be developed.

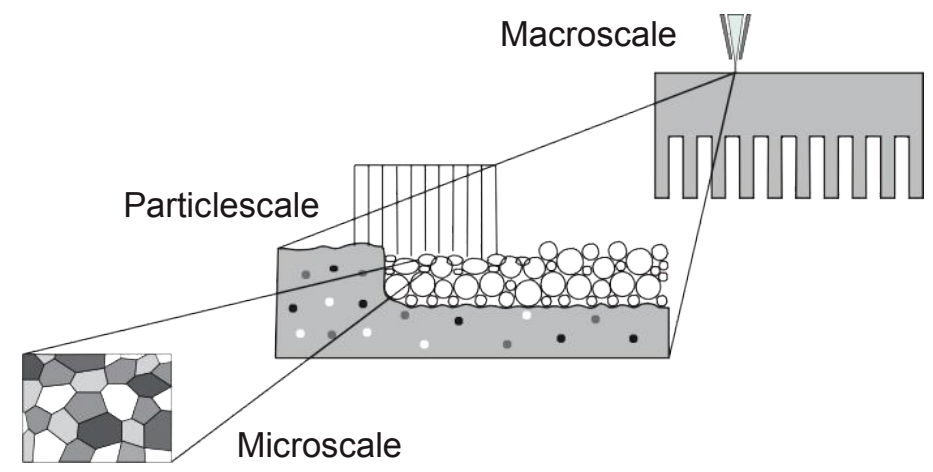

Fig. 20. Multiscale approach for modeling additive manufacturing processes.

SI. 20. Višeskalni postupak za modeliranje aditivnih proizvodnih procesa.

\subsection{Emerging Areas}

Other areas that are under investigation in different research groups are numerous. Among them are fictitious domain methods that allow for the efficient discretization of very complex problems, for which meshing with finite elements is very difficult. For fluid lattice Boltzmann methods offer a very efficient solution for a wide range of problems, even exceeding the limits of the Navier-Stokes equations. Non-intrusive coupling methods allow for performing model-adaptive simulations based on the existing, welldeveloped solvers. Uncertainty modeling and stochastic approaches are necessary for obtaining more reliable predictions in engineering, science and medicine.

Finally, a tremendous development of Artificial Intelligence (AI) techniques influenced the development of many fields in the previous decades. Machine learning and manifold 
learning, and, notably, deep learning techniques, have contributed to an unprecedented growth in the wide range of engineering applications as well. This might lead to a change in the way design of engineering structures and processes is performed. Hence, data-enabled science and engineering can be today looked at as a symbiosis of theory, experiments, simulation and artificial intelligence.

\section{References}

[1] Aldakheel, F., Wriggers, P., Miehe, C. A modified Gurson-type plasticity model at finite strains: formulation, numerical analysis and phase-field coupling. Computational Mechanics, https://doi.org/10.1007/s00466-017-1530-0, 2017.

[2] Aldakheel, F. Mechanics of nonlocal dissipative solids: gradient plasticity and phase field modeling of ductile fracture. Ph.D. thesis, Institute of Applied Mechanics (CE), Chair I, University of Stuttgart. https://doi.org/10.18419/opus-8803, 2016.

[3] Aldakheel, F., Hudobivnik, B., Hussein, A., Wriggers, P. Phase-Field Modeling of Brittle Fracture Using an Efficient Virtual Element Scheme, Computer Methods in Applied Mechanics and Engineering 341, 443-466, 2018.

[4] Avci B., Wriggers P. A DEM-FEM coupling approach for the direct numerical simulation of 3D particulate flows. J Applied Mechanics 79, 010901-(1-7), 2012.

[5] Beirão Da Veiga, L., Brezzi, F., Marini, L.D. Virtual Elements for linear elasticity problem, SIAM Journal on Numerical Analysis 51(2), 794-812, 2013.

[6] Bianchi D., Monaldo E., Gizzi A., Marino M., Filippi S., Vairo G. A FSI computational framework for vascular physiopathology: A novel flow-tissue multiscale strategy. Med. Eng. Phys. 47, 25-37, 2017.

[7] Bourdin, B., Francfort, G.A., Marigo, J.J. Numerical experiments in revisited brittle fracture Journal of the Mechanics and Physics of Solids 48, 797-826, 2000.

[8] Ferziger, J.H., Peric, M. Computational methods for fluid dynamics, $3^{\text {rd }}$ ed., Springer, Heidelberg, 2012

[9] Gusarov, A.V., Yadroitsev, I., Bertrand, P., Smurov, I. Model of radiation and heat transfer in laser-powder interaction zone at selective laser melting. Journal of Heat Transfer, 131(7):072101, 2009.

[10] Jasak, H. OpenFOAM: open source CFD in research and industry, International Journal of Naval Architecture and Ocean Engineering, 2, 89-94, 2009.

[11] Holl, M, Loehnert, S, Wriggers, P. An adaptive multiscale method for crack propagation and crack coalescence International Journal for Numerical Methods in Engineering 93 (1), 23 51, 2013.

[12] Hudobivnik, B, Aldakheel, F, Wriggers, P. Low order 3D virtual element formulation for finite elastoplastic deformations, Computational Mechanics https://doi.org/10.1007/s00466018-1593-6, 2018.

[13] Korelc, J, Wriggers, P. Automation of Finite Element Methods, Springer, Berlin, 2016. 
[14] Krafczyk, M., Tölke, J., Luo, L.S. Large-eddy simulations with a multiple-relaxation-time LBE model, International Journal of Modern Physics B 17, 33-39, 2003.

[15] Kuna, M. Numerische Beanspruchungsanalyse von Rissen, Vieweg \& Teubner, 2008.

[16] Marino M. Constitutive Modeling of Soft Tissues. In: Hellmich C. (Ed.), Encyclopedia of Biomedical Engineering - Biomechanics, Elsevier. doi: 10.1016/B978-0-12- 801238-3.99926-4, 2018.

[17] Marino M, Wriggers P. Finite strain response of crimped fibers under uniaxial traction: an analytical approach applied to collagen. Journal of the Mechanics and Physics of Solids. 98, 429-453, 2017.

[18] Marino M, Pontrelli G, Vairo G, Wriggers P. A chemo-mechano-biological formulation for the effects of biochemical alterations on arterial mechanics: the role of molecular transport and multiscale tissue remodelling. Journal of the Royal Society, Interface 14: 20170615 , 2017.

[19] Marino M. Molecular and intermolecular effects in collagen fibril mechanics: a multiscale analytical model compared with atomistic and experimental studies. Biomechanics and Modeling in Mechanobiology 15, 133-154, 2016.

[20] Hron, J., Turek, S. A monolithic FEM/multigrid solver for an ALE formulation of fluidstructure interaction with applications in biomechanics, Fluid-structure interaction, 2006.

[21] Wessels, H., Bode, T., Weißenfels, C., Wriggers, P., Zohdi, T.I. Invetigation of heat source modeling for selective laser melting. Computational Mechanics, accepted for publication, 2018.

[22] Wessels, H., Weißenfels, C., Wriggers, P. Metal particle fusion analysis for additive manufacturing using the stabilized optimal transportation meshfree method. Computer Methods in Applied Mechanics and Engineering, 339:91114, 2018.

[23] Weißenfels, C., Wriggers, P. Stabilization algorithm for the optimal transportation meshfree approximation scheme. Computer Methods in Applied Mechanics and Engineering, 286:87106, 2017.

[24] Wriggers, P., Reddy, B.D., Rust, W., Hudobivnik, B. Efficient virtual element formulations for compressible and incompressible finite deformations, Computational Mechanics 60, 253268, 2017. 


\section{RAČUNALNA MEHANIKA \\ U ZNANOSTI I INŽENJERSTVU - QUO VADIS}

\section{Sažetak}

Računalna mehanika ima široku primjenu u znanosti i inženjerstvu. Njeno područje primjene se znatno povećalo u zadnjim desetljećima. Danas polja kao biomehanika i aditivna proizvodnja nova su područja istraživanja u kojima računalna mehanika pomaže rješavati složene probleme i procese. U radu se razmatraju ova granična područja zajedno s novim diskretizacijskim postupcima kao što su metoda virtualnih elemenata i metoda čestica, gdje potonja zahtijeva moćnu računalnu opremu da bi se mogli točno riješiti problemi kao što je miješanje. Analiza oštećenja konstrukcija i njenih komponenata je drugo područje koje se brzo razvija, pa se ovdje moderni računalni postupci odnose na metodu faznih polja koja pojednostavljuje diskretizacijske sheme. Svi navedeni postupci i metode su razmatrani i vrednovani u numeričkim primjerima.

Ključne riječi: Metoda virtualnih elemenata, biomehanika, aditivna proizvodnja, metoda faznih polja, metoda diskretnih elemenata, medusobno djelovanje fluida i čestice

\footnotetext{
Peter Wriggers*, Fadi Aldakheel, Michele Marino, Christian Weißenfels

Leibniz Universität Hannover

Institute for Continuum Mechanics, Faculty of Mechanical Engineering, Appelstr. 11, 30161 Hannover,

E-mail:wriggers@ikm.uni-hannover.de; aldakheel@ikm.uni-hannover.de; marino@ikm.uni-hannover.de; weissenfels@ikm.uni-hannover.de

* corresponding member HAZU
} 